\title{
HISTORIA HISTORIOGRAFII - KRYZYS, RECEPC]A, DIALOG
}

\author{
Maciej BUGAJEWSKI, Violetta JULKOWSKA, Maria SOLARSKA
}

Uniwersytet im. Adama Mickiewicza w Poznaniu

\section{CZAS KRYZYSU}

Gwałtowne przemiany cywilizacyjne, które do niedawna wydawały się znaczącym, lecz wciąż zaledwie kontekstem badań historycznych i form ich autorefleksji, współcześnie wywołują konieczność przedefiniowania tożsamości i zadań historiografii, historii dziejopisarstwa, metodologii badań historycznych oraz praktyk przekazywania ich rezultatów w szkolnych i pozaszkolnych kontekstach dydaktyczno-edukacyjnych.

W jednym z tekstów zbioru, który przekazujemy w ręce Czytelnika, owe najogólniejsze w swojej wymowie przemiany zostały uchwycone w lapidarnym wyliczeniu obejmującym cyfryzację, ponowoczesność i globalizację. Jednak nie mniej ważne dla podejmowanych w tym tomie problemów są aktualne wydarzenia polityczne na scenach od lokalnej po światową. U progu nowego wieku przyniosły one wstrząsy na wielu płaszczyznach, od których przemyślenia zależy przyszłość naszych dyscyplin badawczych i praktyk edukacyjnych.

1 Idea zestawienia tomu tematycznego czasopisma Historia@Teoria, poświęconego współczesnej kondycji historii historiografii, powstała w naszym zespole redaktorskim latem 2016 roku. Od samego początku tej inicjatywy wydawniczej podzielaliśmy przekonanie, że należy spojrzeć na naszą dyscyplinę badawczą możliwie szeroko, biorąc pod uwagę współczesne przemiany cywilizacyjne, innowacyjne metody badawcze stosowane przed historyków historiografii, wreszcie aktualne dylematy epistemologiczne i etyczne. W niniejszym wprowadzeniu akcentujemy niektóre z tych kontekstów i perspektyw, szczególnie te, które uzyskały rozwinięcie w tekstach nadesłanych przez Autorów. Tom powstawał w otwartym dialogu w zespole redaktorskim. Sądzimy, że wymiana myśli między Autorami tekstów tworzących tom uruchomi się również w spojrzeniu Czytelnika podczas lektury. Dialogiczny charakter postanowiliśmy zachować także we wprowadzeniu. Dzięki wymianie myśli i głosów nasze wspólne myślenie o historiografii staje się pełniejsze, gdyż uwzględnia zarówno promowaną przez Violettę Julkowską ideę historii historiografii jako recepcji (zob.: punkt drugi wstępu Sztuka recepcji), dialogiczną koncepcję prawdy szkicowaną przez Marię Solarską (zob.: niżej Pochwałę dialogu) i uwrażliwienie na wymiary współczesnego kryzysu cywilizacyjnego i naukowego, wyrażane przez Macieja Bugajewskiego (Czas kryzysu). Solidaryzujemy się wzajemnie z kierunkami autorskiej refleksji każdego z nas. 
Jeszcze do niedawna mogliśmy z uzasadnioną, jak się zdawało, ufnością w utrwalone wzorce postępowania badawczego dystansować się od ponowoczesnych nowinek podważających tożsamości naszych dyscyplin. Wszak te ostatnie zdawały się w swych fundamentach nienaruszalne. Gdy jednak dzisiaj okazuje się, że nowe idee, nie tyle projektowały nowe sposoby egzystowania jednostek i społeczeństw, lecz raczej byly formami refleksji nad rzeczywistymi, już dokonanymi, gruntownymi przekształceniami życia społecznego, to znaczy formami autorefleksji rzeczywistej dynamiki kultury, strategie dystansowania się historiografii od form współczesności wyjawiają swoją anachroniczność i nie najlepiej rokują na przyszłość.

Kategoria ponowoczesności określa przekształcenia w życiu społecznym polegające między innymi na zredefiniowaniu relacji między normą a normowanym, centrum i peryferiami, jednostką i grupą, mową i działaniem, badawczym odkrywaniem a swobodnym wyobrażaniem, władzą i jej podlegającymi, przeszłością i teraźniejszością. Globalizacja, której istotą na jednej z płaszczyzn jest zmniejszenie znaczenia państw w wytwarzaniu historii na rzecz działania transnarodowych podmiotów i procesów o światowym zasięgu, skutkuje niespotykaną dotychczas społeczną atomizacją przynoszącą zagrożenia jednostkom wydanym na przemożne oddziaływanie sił zaangażowanych w grę podmiotów globalnych. Cyfryzacja przynosi fundamentalną przemianę form komunikacji społecznej, której skutkiem, być może najbardziej dotkliwym, będzie faktyczny zanik formy narracyjnej jako dominującego medium rozpoznawania tożsamości. Mamy zatem współcześnie do czynienia z gwałtownym przyspieszeniem przemian historycznych podsycanym w sferze politycznej między innymi przez odwrót (gdzieniegdzie) od standardu demokratycznego, kryzys związany z relacjami ze światem islamu, wzrost tendencji imperialnych w niektórych częściach globu.

Jednym z efektów współczesnego wzburzenia oceanu dziejów, dostrzegalnym z perspektywy profesjonalnego zaangażowania autorów niniejszego tomu studiów, jest odczuwany przez wielu historyków kryzys tożsamości aplikacyjnych (edukacja) i badawczych dyscyplin historiograficznych. W dziedzinie historiografii kryzys tożsamości polega przede wszystkim na tym, że niejednokrotnie odczuwamy jako coraz bardziej nieefektywny tradycyjny model uznawania tekstu narracyjnego za tekst należący do gatunku historiograficznego. Model ów definiuje (wyrażając go w wielkim uproszczeniu), że do historiografii należą, zakwalifikowane do niej przez wspólnoty badawcze historyków, teksty odnoszące się do przeszłości społeczeństw, narodów i państw, będące rezultatem uregulowanego w określony sposób (metodycznego) postępowania ze źródłami historycznymi, 
przede wszystkim pisanymi. Coraz trudniej jest jednak określać w ten sposób historiograficzność w sytuacji, gdy: (1) ponowoczesne społeczeństwo na różne sposoby podważa autorytet wspólnoty badawczej uczonych i jej wyłączność w zakresie kompetencji do uznawania obrazów przeszłości; (2) jednocześnie w obrębie historiografii powstają liczne prace czerpiące z metodyk innych nauk o kulturze i społeczeństwie, wykraczających poza model krytycznej egzegezy tekstu pisanego; a zarazem (3) wraz z przemianami struktur społecznych zmniejsza się rola tradycyjnego przedmiotu zainteresowań historiografii (państwo, naród), które okazują się współcześnie zaledwie mediatorami między zatomizowanymi jednostkami i strukturami globalnymi.

Kryzys tożsamości w zakresie metodologii historii (teorii historii) nie polega już dzisiaj wyłącznie na tym, że - jak od samego początku tego typu badań - można odczuć napięcie między ich filozoficznymi założeniami i celami a dorobkiem historiografii, będącym ich przedmiotem badawczym. Kryzys ten jest pochodną współczesnego kryzysu tożsamości historiografii, a dla metodologii historii oznacza niebezpieczeństwo bądź skupienia się na wytwarzaniu spekulatywnych wyobrażeń o historiografii (będących bardziej projektami niż opisami), bądź kontentowania się ogólną refleksją nad trybami społecznych odniesień do przeszłości.

Kryzys tożsamości nauk historycznych dostrzegamy również w zakresie edukacji historycznej. W tym przypadku kryzys polega na coraz większej różnicy między tym, o kim się mówi, a tym, do kogo się mówi podczas praktyki edukacyjnej. Różnica ta wynika z poczucia historycznego lub kulturowego (cywilizacyjnego) cięcia między współczesnością i przeszłością. Uczniowie i studenci formowani w erze ponowoczesności, globalizacji i cyfryzacji z narastającym, jak się wydaje, dysonansem przyjmują wykładnię przeszłości opartą na założeniach sprzed epoki dzisiejszych gwałtownych przemian cywilizacyjnych lub (w przypadku mieszczącym się na drugim biegunie możliwych reakcji nauczanych) odbierają z przejęciem opowieść o przeszłości nie dostrzegając jednak w niej prawdziwej genezy swojej własnej rzeczywistości społecznej. Odczuwają przeszłość w myśl zasady - dawne czasy byly bardzo interesujące (ważne, podniosłe, okrutne itp.), jednak my pochodzimy jakby nie wiadomo skąd (tak duża jest dla nich przerwa między przeszłością a innym niż dawne dniem dzisiejszym). Aktywizujące ucznia i studenta metody nauczania łagodzą ten dysonans, nie znosząc go jednak w pełni.

Historia historiografii kształtuje się wciąż na nowo w kontekście naszkicowanych wyżej okoliczności cywilizacyjnych, naukowych i edukacyjnych. Jak w każdej sytuacji kryzysowej, tak również i dzisiaj historycy historiografii stoją przed pytaniem 
o to, w jakim zakresie kontynuować dotychczasowe osiągnięcia i wzorce swojej dyscypliny, a w jakim poszukiwać dla niej dróg dotychczas nieznanych. Czym mogłaby być historia historiografii w przyszłości, nie zrywająca jednak ze swoją przeszłością? Współczesny kryzys historii historiografii, mimo podobieństw do naszkicowanej wyżej sytuacji w innych dyscyplinach historiograficznych, posiada swoistości związane ze specyfiką tej dyscypliny badawczej. O podzielenie się przemyśleniami na temat przeszłości i przyszłości historii historiografii poprosiliśmy naszych Mistrzów i badaczy o uznanym autorytecie z wiodących ośrodków badań historiograficznych w naszym kraju. Punktem wyjścia dyskusji była rozesłana przez nas ankieta, w której pytaliśmy o miejsce historii historiografii w dziedzinie nauk historycznych, o rekomendacje lektur, o kwestie związane z naukowością badań z zakresu historii historiografii, o problemy dydaktyczne związanej z nauczaniem uniwersyteckim. Jednak nasza ankieta była tylko zagajeniem refleksji i dyskusji nad żywym depozytem przeszłości i przyszłością naszej dyscypliny.

Być może najlepszym wprowadzeniem czytelnika do lektury tekstów niniejszego tomu jest zwrócenie uwagi na miejsce, jakie w rozważaniach naszych autorów zajmuje pojęcie „dziejopisa” i inne z nim powiązane. Dziejopis to z jednej strony historyk, mniej lub bardziej profesjonalny, jednak w sytuacji współczesnych przemian cywilizacyjnych „dziejopisami” w jakimś sensie stają się liczni inni interesariusze przeszłości - politycy, dziennikarze, muzealnicy, przedstawiciele kościołów, pisarze i inni. Ich głos brzmi coraz donioślej, w miarę jak słabnie autorytet i przekaz zawodowych historyków. Sytuacja ta oznacza kluczowy dylemat współczesnego historyka dziejopisarstwa (historiografii) - czy wiązać swój los z losem nauki historycznej w sensie ścisłym, czy też rozszerzać zainteresowanie na inne formy „dziejopisarstwa”, nie mieszczące się w obrębie nauki historycznej? Druga strategia, w pewnym zakresie nieunikniona, oznacza przekształcenie tożsamości naszej dyscypliny. Potrzebujemy tutaj roztropności i dobrej miary. Jako redaktorzy naukowi przedsięwzięcia, wierzymy, że Czytelnik znajdzie najlepsze z możliwych dzisiaj odpowiedzi w tekstach zestawionych w niniejszym tomie.

\section{SZTUKA RECEPC]I}

W dyskusji, jaką prowadzą od kilku lat historycy historiografii, formułowane są próby określenia ram własnej dyscypliny, jej roli i zakresu, obszarów i tematów obejmowanych badaniem. $Z$ tych wypowiedzi, mimo różnicy poglądów, wyłania się potrzeba zaakcentowania tożsamości historii historiografii poprzez odróżnienie jej od historii rozumianej jako historia rerum gestarum. 
Historia historiografii, jako jedna z form refleksji nad pisarstwem historycznym (obok na przykład metodologii historii), artykułowana jest w metajęzyku w stosunku do języka prac historiograficznych. Nasza dyscyplina badawcza nie tylko dokumentuje historyczny rozwój historiografii, ale także tym samym dokonuje czegoś w rodzaju autorefleksyjnego ujęcia historiograficznego pola. Jest to zadanie tym trudniejsze, im bardziej rozszerza się współczesne spektrum problemowo-tematyczne prac historycznych. Wiek XX wzbogacił dorobek historiograficzny o kilkadziesiąt nowych kierunków, szkół i orientacji, jakie pojawiły się w nauce historycznej. Wiek XXI bynajmniej nie zapowiada się mniejszą aktywnością historyków. Już samo dokonanie klasyfikacji prac pod względem pól problemowych staje się zadaniem trudnym, podobnie jak ich kompetentna krytyka naukowa.

Z perspektywy najbardziej ogólnej i pragmatycznej, jaką jest szeroki rynek wydawniczy prac o tematyce historycznej, należy postawić pytanie o to, czy historia historiografii poza funkcją archiwizująco-interpretacyjną posiada również specyficzną kompetencję krytyczną? Czy koncentrując się głównie na niszy naukowych prac historycznych nadal ma w swej gestii ocenę tych prac? Według jakich kryteriów miałaby się ona dokonywać, jeśli miałaby być realizowana przez specyficzny dla historii historiografii sposób waloryzacji prac historycznych? W zalewie wydawnictw komercyjnych, rynek książki naukowej w dawnym rozumieniu, oznaczającym wyspecjalizowane i dofinansowywane wydawnictwa o dużych nakładach i celowo zorganizowanej dystrybucji, zdaje się nie istnieć. Zwrócenie uwagi na pracę historyczną poprzez fachową recenzję, które jeszcze nie tak dawno miało wartość udzielenia rekomendacji, rzadko przeradza się w dyskusję, ograniczając się do wewnątrzśrodowiskowej informacji o ograniczonym zasięgu.

Włączenie tytułu pracy do bibliografii i jej zacytowanie na kartach dzieła syntetycznego historii historiografii oznaczało jeszcze nie tak dawno dla wielu badaczy historii i ich prac otwarcie drogi do kanonu historiograficznego. Historia historiografii utrwalała i zachowywała pamięć o autorach i tytułach w polu historiografii. Czy nadal tak jest? Jaki jest współczesny status historii historiografii widzianej spoza tej dyscypliny przez historyka, który na co dzień nie zajmuje się tą wyspecjalizowaną dziedziną, pozostając czytelnikiem krytycznym prac historycznych?

Historia historiografii to dziedzina badawcza stosunkowo młoda, jeśli spojrzymy na przedmiot jej badań, jakim są dzieje badań historycznych. Z jednej strony historia pisana jest w naszym kręgu kulturowym od czasów starożytnej Grecji, ale z drugiej jako dyscyplina o własnym programie i zakresie badań wyłania się 
stosunkowo późno, bo w pełni wyodrębnia się na przełomie XVIII i XIX wieku. Dopiero wówczas historia staje się świadomą celu badawczego profesjonalną aktywnością naukową a historia historiografii jej istotną składową. Powstaje pytanie, co zatem powinna badać historia historiografii? Czy każdą aktywność kulturową w postaci spisywania dziejów, czy też powinna ograniczyć się do prac powstałych wraz z wyznaczeniem pierwszych kryteriów naukowości na uniwersyteckich seminariach historycznych przeszło dwieście lat temu?

Dla uprawianej przez historyków profesji historia historiografii, jako jedna z form jej autorefleksji, jest rodzajem wiedzy o drogach jej rozwoju oraz o tych, którzy ją tworzyli. Jest świadectwem ich zmysłu obserwacji i przenikliwości w ocenie bieżących wydarzeń, lub arbitralności sądów wydawanych post factum. Historia historiografii jest bowiem swoistym archiwum refleksji o autorach i tekstach uznawanych za historiograficzne w danym momencie dziejów. Specyficzność tego archiwum polega na zmiennych kryteriach klasyfikacji, interpretacji i oceny, stosowanych wobec przechowywanych w nim dzieł dawnych i nowo przybywających.

Historia historiografii analizując, interpretując i waloryzując prace historyczne ustanawia wprost lub pośrednio nienormatywne kanony pisarstwa historycznego. Znajomość szerokiego historycznego kontekstu badań historiograficznych sprzyja kształtowaniu się kompetencji krytycznej historyków historiografii. Historia dziejopisarstwa, to próba uchwycenia koncepcyjnego i artystycznego kunsztu historiografii w obszarze licznych tematów podejmowanych przez historyków. Na kartach niniejszego tomu Czytelnik odnajdzie namysł nad tymi, którzy dzieje historii piszą, nad specyficznymi kompetencjami, które powinni posiadać, nad tym wreszcie, co różni pod względem kompetencji i celów badawczych historyka historiografii wypowiadającego się na temat historiografii określonej epoki od historyka tejże epoki.

Specjalizacja, polegająca na badawczym zajmowaniu się historiografią pisaną w danym okresie historycznym, to często jedyny sposób na głębokie wniknięcie do poziomu semantycznego prac historycznych i historycznego języka epoki oraz oddanie kultury historycznej dawnej w kategoriach kultury historycznej czasów, w których wypowiada się historyk historiografii. $\mathrm{Z}$ tego powodu nieuchronna jest różnica kompetencji i zadań badawczych między historykiem historiografii i historykiem epoki, której dotyczy historiografia analizowana przez historyka historiografii. Dla uprawiania historii historiografii nie wystarczy przeświadczenie, 
że jeśli się bada źródła historyczne należące do epoki, którą zajmuje się dane dzieło historiograficzne, to tym samym nabywa się kompetencji do analizy kontekstu historiograficznego tego dzieła, satysfakcjonującej z punktu widzenia standardów historii historiografii. Historyk historiografii, wprowadzając perspektywę historyczną, to znaczy również wiedzę kontekstową o rozwoju historiografii, włącza do interpretacji tekstów nie tylko inny, szerszy horyzont doświadczenia historiograficznego, ale również kompetencję odczytywania sensu danego tekstu z perspektywy obcej temu tekstowi, późniejszej świadomości.

Jeśli spojrzymy na historyka historiografii jako na refleksyjnego Czytelnika, to spróbujmy zobaczyć Go jako nieznużonego lekturą książek historycznych, sięgającego po nowe i mającego w pamięci prace już przeczytane. Jednak Czytelnik ten nie tylko rejestruje przybywające na gruncie badań historycznych nowe opracowania, nie tylko odnosi się do twórczości historycznej poszczególnych historyków, tworząc klasyczne biografie naukowe. Historyk historiografii nade wszystko uruchamia podczas analizy i interpretacji dzieł historycznych cenione przez siebie konteksty współczesnej humanistyki, które - jak wierzy - umożliwiają ex post rozumienie i problematyzację dzieł historycznych. I właśnie w ten sposób historyk historiografii, Czytelnik zarazem przeszłości i współczesności, obejmuje spojrzeniem możliwie najszerszy horyzont pisarstwa historycznego i zawartego w nim doświadczenia historii.

\section{POCHWA $Ł A$ DIALOGU}

Jeżeli trzeba byłoby scharakteryzować niniejszy tom jednym słowem, to „wielogłos” lub „różnorodność” byłyby chyba najwłaściwszymi. Dobrze oddawałyby też jego wartość.

Zamysł towarzyszący niniejszemu tomowi zakładał stworzenie pola dyskusji nad współczesną historią historiografii. Efektem, który chcieliśmy osiągnąć było przedstawienie różnych punktów jej widzenia, różnych praktyk ich realizowania. Nie chodziło zatem o ustalenie w podsumowaniu jedynego słusznego jej modelu, ale o uchwycenie etapu, na którym znajduje się jej autorefleksja.

Czy dyskusje wokół granic dziedziny i jej pytania o swój przedmiot, podejścia, o to czym jest, są przejawem jej słabości, czy wręcz przeciwnie jej żywotności? Czy jej dylematy dotyczące miejsca w dynamicznie zmieniającej się rzeczywistości otaczającej, świadczą o kryzysie w jakim znalazła się wraz z pokrewnymi obszarami badania, czy też o jej otwartości na współczesność, 
zamiast zamykania się w wieży słoniowej swej domniemanej mądrości? Można zasadnie argumentować na rzecz obu sposobów postrzegania sytuacji współczesnej historii historiografii - zarówno widzieć niebezpieczeństwo w jej kryzysie i rozmywającej się tożsamości, jak i szansę, żywotność i wyznania, które mogą przyczynić się do jej rozwoju.

Zmiany w otaczającej rzeczywistości zwykle wydają się współczesnym szczególne, wyjątkowe. Ich dynamika jest niepowtarzalna, bo obserwowana w ciągu naszego życia. Ta szczególność czasów przeżywanych nieobca jest badaczkom i badaczom historii, o tym wszak opowiadają - o niepowtarzalności i szczególności nieustannie wydarzającej się w dziejach.

Problemy i rozterki historii historiografii są pochodnymi tych, z którymi zmaga się współczesność, ale też nauka, a szczególnie humanistyka. Być może największym wyzwaniem, z którym musi się zmierzyć jest odpowiedź na pytanie czy nadal jest ona dziedziną refleksji nad wartościami, które mają określać naszą wspólnotę kulturową i nad sposobami ich realizacji, czy też jej rola ma się sprowadzać do rozpoznawania spontanicznie ustanawianych reguł gry i podejmowania odpowiednich strategii dopasowania się do nich. Czy w tym drugim przypadku wspólnota badawcza nie sprzeniewierza się wartościom etycznym będących jej podstawą i nie podważa sensu swych działań? Z pewnością rozstaje się z określoną formą swej tożsamości.

Jerzy Topolski wyróżnia trzy rodzaje badań nad rzeczywistością minioną: historię właściwą, metodologię historii i historię historiografii. Wskazuje na odmienne pola ich zainteresowań, ale zwraca uwagę na ich wzajemne przenikanie i powiązania. Konsekwencje tego splątania widać w prezentowanych w tomie podejściach - zbliżających historię historiografii bardziej do historii właściwej lub bardziej do metodologii historii. Czy oznacza to, że zmierza ona do rozpłynięcia się w jednej lub drugiej? Niekoniecznie. Rozpoznając i poddając refleksji coraz więcej wymiarów rzeczywistości, proponując nowe perspektywy jej oglądu, dysponując coraz większym zasobem wiedzy różnego typu musimy pogodzić się z tym, że nie jesteśmy w stanie ich jednostkowo opanowywać. Musimy pogodzić się z „podziałem pracy”, ze specjalizowaniem się w węższych dziedzinach. Wraz z tym trzeba jednak nauczyć się lub udoskonalić sposoby współpracy i dialogu między specjalnościami. Do tego potrzebne jest określenie swoich pozycji i właściwych im kompetencji. Jednak okopywanie się w nich lub wzajemna „kanibalizacja” nie 
przyczynią się przecież do tego, „by tym bardziej krzewiła się prawda i jaśniej błyszczało jej światło, od którego zależy dobro rodzaju ludzkiego" (co ślubujemy podejmując karierę badawczą).

Wyodrębnienie się historii historiografii w ramach badań historycznych jest ważnym etapem rozwoju nauki historycznej, wyrazem jej autorefleksji i konsekwencji w historycznym traktowaniu świata bez wyłączania z niego samej siebie. To całościowe spojrzenie na historiografię jako zjawisko społeczne, kulturowe, zmienne historycznie czyni różnicę między traktowaniem tekstów historiograficznych przez historyków danych epok a ich ujmowaniem przez historyków historiografii. I ta różnica stwarza możliwość dialogu wiodącego ku prawdzie, lepszemu rozumieniu świata minionego i otaczającego, ku wiedzy, która pomaga lepiej żyć.

Różnorodność - nurtów badawczych, perspektyw oglądu, przedmiotów zainteresowania - to ogromna zaleta historiografii, zarówno współczesnej, jak i widzianej w perspektywie dziejowej - różnorodności form i kształtów, które przyjmowała. Wielogłos to najlepszy sposób poszukiwania prawdy, dążenia do niej, a największym dla niej zagrożeniem jest ogłoszenie jednej prawdy jako jedynej możliwości. To koniec historii jako badania.

Zderza się to z naszą potoczną potrzebą jednoznacznych ustaleń stanów rzeczywistości - ale czy potrzeba ta odnosi się do jednoznacznej prawdy, czy do potrzeby ustalania, pod pozorem prawdy, kto jest dobry a kto zły oraz oczekiwania ogłoszenia, że „my” to ci dobrzy?

Oddani refleksji nad różnorodnością i złożonością świata, czujemy swego rodzaju bezradność wobec głosów proponujących proste rozwiązania i rozstrzygnięcia. Bezradność ta wynika ze znalezienia się w sytuacji, kiedy silę argumentów zastępuje argument siły. Być może największym wyzwaniem stojącym przed nauką historyczną jest bowiem to, jak obronić wartości kulturowe, które ją tworzą - krytyczny dystans do rzeczywistości, rolę szacunku dla innych punktów widzenia (o ile nie zakładają one dewaluacji odmiennych od niego), znaczenie poszukiwań rozwiązań respektujących wartości konstytuujące wspólnotę.

Reflektując nad tradycją historii historiografii oraz nad jej możliwą i pożądaną przyszłością, bronimy się przed ziszczeniem się zdania znanego z epoki słusznie minionej, że przyszłość jest znana, a przeszłość dopiero trzeba ustalić. 